\title{
UPAYA MEDIASI DALAM PENYELESAIAN SENGKETA DI LEMBAGA PERBANKAN
}

\author{
Suherman \\ Fakultas Hukum Universitas Pembangunan Nasional "Veteran” Jakarta \\ Email: suherman.sh02@gmail.com
}

\begin{abstract}
Abstrak
Di banyak negara penggunaan mediasi sebagai metode penyelesaian sengketa pada mulanya bersifat sukarela (voluntary). Dalam sengketa perbankan yang berawal dari keluhan nasabah terhadap pelayanan suatu bank yang apabila tidak ditanggapi akan menimbulkan sengketa. Sengketa perbankan juga bisa terjadi karena hubungan kontrak antara bank dengan debitur. Ada beberapa langkah yang dapat dilakukan oleh debitur dalam melakukan mediasi perbankan yaitu debitur melakukan pertemuan dengan pihak bank untuk meminta penjelasan untuk melakukan mediasi apabila telah paham dan mengerti maka debitur dapat mengajukan proses mediasi ke pelaksanaan fungsi mediasi perbankan, debitur mengikuti proses mediasi dengan baik dan menuangkan dalam suatu kesepakatan. Dalam hal ini juga penulis menjabarkan tentang keuntungan dan kelemahan dengan mediasi perbankan.
\end{abstract}

Kata kunci: Mediasi, Sengketa, Perbankan

\begin{abstract}
In many countries the use of mediation as a method of dispute settlement was initially voluntary. The banking dispute that begins with a costumer's complaint against the services of a bank which is not responded, will cause a dispute. The banking dispute can also occur due to contractual relationship between bank and debtor. There is several action that can be done by debtor for doing banking mediation, namely debtor has meeting with bank party to ask explanation for mediation, if acknowledge and understand so debtor can propose a mediation process to the implementation of banking mediation function, the debtor follows the mediation process and put it into an agreement. In this case, author also describe the benefits and weakness about banking mediation.
\end{abstract}

Keywords: Mediation, Dispute, Banking

\section{A. PENDAHULUAN}

\section{Latar Belakang}

Bank adalah sebagai lembaga yang menghimpun dana masyarakat dalam bentuk kredit atau pembiayaan lainnya. Perbankan mempunyai peranan penting dalam perekonomian di Indonesia. Perbankan juga sebagai lembaga keuangan yang berperan sangat penting dalam aktivitas pembangunan nasional serta perdagangan internasional. Bank adalah lembaga keuangan yang menjadi tempat bagi perseorangan, badan-badan usaha swasta bahkan, lembaga-lembaga pemerintahan menyimpan danadana yang dimilikinya. Di Indonesia masalah yang terkait dengan bank diatur dalam Undang-Undang Perbankan No. 7 Tahun 1992 dan No. 10 Tahun 1998, berkaitan dengan pengertian bank, dalam Pasal 1 butir 2 UU Perbankan merumuskan bahwa bank adalah badan usaha yang menghimpun 
dana dari masyarakat dalam bentuk simpanan dan menyalurkannya kepada masyarakat dalam bentuk kredit dan atau bentuk lainnya dalam rangka meningkatkan taraf hidup orang banyak. ${ }^{1}$

Dalam dunia perbankan, nasabah merupakan konsumen yang harus mendapatkan pelayanan dengan baik dan mempunyai peran yang sangat penting dari hidup matinya dari suatu bank. Dalam interaksi antara bank dan nasabah mungkin sering terjadi kesalahpahaman atau gesekan antara bank dan nasabah.yang apabila tidak segera diselesaikan maka akan menimbulkan sengketa antara nasabah dengan bank. Berbagai keluhan dari nasabah bisa menimbulkan sengketa yang disebabkan oleh kesalahan dari bank yang menjalankan usahanya. Meskipun sebenarnya telah ada regulasi yang mencoba melindungi nasabah bank, akan tetapi tidak menutup kemungkinan juga terjadinya sengketa yang berujung pada sengketa antara nasabah dan bank, terutama terkait dengan permasalahan kredit macet dan lain sebagainya. Sengketa tersebut juga tidak jarang berujung pada gugatan di Pengadilan oleh salah satu pihak yang tentunya akan merugikan kedua belah pihak itu sendiri baik dari segi waktu, energi, dan tentunya biaya.

Berdasarkan Undang-undang No. 30 tahun 1999 tentang Arbitrase dan Alternatif Penyelesaian Sengketa, yang di dalamnya memberikan berbagai alternatif dalam menyelesaikan sengketa di luar Pengadilan secara cepat, murah dan sederhana. Model penyelesaian sengketa dimaksud dalam Undang-undang tersebut adalah model arbitrase, konsultasi, mediasi dan konsiliasi atau penilaian ahli. Dengan model-model tersebut diharapkan berbagai sengketa yang terjadi bisa diselesaikan dengan win-win solution, termasuk dalam sengketa perbankan. ${ }^{2}$

Dalam dunia perbankan sendiri telah ada Peraturan Bank Indonesia (PBI) No.8/5/PBI/2006 yang kemudian dirubah dengan PBI No.10/1/PBI/2008 tentang Mediasi Perbankan. PBI ini memberikan alternatif dalam menyelesaikan sengketa antara nasabah dan bank memalui proses mediasi pada apa yang dinamakan Lembaga Mediasi Perbankan (LMP). Tulisan ini akan berusaha memberikan deskripsi bagaimana langkah yang dapat dilakukan oleh debitur dalam melakukan mediasi perbankan dan keuntungan dan kelemahan dengan mediasi perbankan.

\section{Rumusan Masalah}

Berangkat dari uraian diatas, maka penulis dapat merumuskan masalah yang akan dibahas dalam tulisan ini yakni bagaimanakah langkah yang dapat dilakukan oleh debitur dalam melakukan mediasi perbankan dan apa keuntungan serta kelemahan dengan mediasi perbankan.

1 Munir Fuady, 1999, Hukum Perbankan Modern, Bandung: Citra Aditya Bhakti, hlm. 5

2 Priyatna Abdurrasyid, 2011, Arbitrase dan Alternatif Penyelesaian Sengketa, Jakarta: PT. Fikahati Aneska, hlm. 16 


\section{B. PEMBAHASAN}

\section{Langkah-Langkah yang Dapat Dilakukan Oleh Debitur Dalam Melakukan Mediasi Perbankan}

Mediasi merupakan suatu proses perdamaian yang dilakukan oleh para pihak yang bersengketa dan dibantu penyelesaiannya oleh seorang mediator demi tercapainya hasil akhir yang adil atau win-win solution, tanpa membuang biaya yang terlalu besar, akan tetapi tetap efektif dan diterima sepenuhnya oleh kedua belah pihak yang bersengketa secara sukarela. Di dalam Undang-Undang Nomor 30 tahun 1999 tidak memberikan definisi apapun tentang apa itu mediasi dan lain sebagainya. Akan tetapi definisi ditemukan dalam Peraturan Bank Indonesia (PBI) No.8/5/PBI/2006 tentang Mediasi Perbankan. Dalam angka 5 PBI tersebut disebutkan bahwa Mediasi adalah proses penyelesaian sengketa yang melibatkan mediator untuk membantu para pihak yang bersengketa guna mencapai penyelesaian dalam bentuk kesepakatan sukarela terhadap sebagian atau seluruh permasalahan yang disengketakan.

Menurut J. Folberg and A. Taylor mediasi adalah The process by which the participants, together with the assistance of aneutral person or persons, systematically isolate disputed issues in order to develop options, consider alternatives, and reach a consensual settlement that will accommodate their needs. ${ }^{3}$ Sedangkan menurut Priyatna Abdurrasyid, mediasi merupakan suatu proses damai dimana para pihak yang bersengketa menyerahkan penyelesaiannya kepada seorang mediator untuk mencapai hasil akhir yang adil tanpa membuang biaya yang terlalu besar, akan tetapi efektif dan diterima sepenuhnya oleh para pihak yang bersengketa secara sukarela. ${ }^{4}$

Tidak sebagaimana halnya seorang hakim atau arbiter, seorang mediator tidak dalam posisi (tidak mempunyai kewenangan) untuk memutus sengketa para pihak. Tugas dan kewenangan mediator hanya membantu dan memfasilitasi pihak-pihak yang bersengketa dapat mencapai suatu keadaan untuk dapat mengadakan kesepakatan tentang hal-hal yang disengketakan.

Mediasi merupakan salah satu alternatif penyelesaian sengketa perbankan. Sedangkan Philip D. Bostwick mengatakan bahwa Alternatif Dispute Resolution adalah a set of practices and legal techniques that aim to permit legal disputes to resolved outside the court for the benefit of all disputants, to reduce the cost of conventional litigation and the delay to which it is ordinarily subjected and to prevent legal dispute that would otherwise likely be brought to the courts. ${ }^{5}$ Alternatif penyelesaian sengketa adalah sebuah perangkat pengalaman dan teknik hukum yang bertujuan menyelesaikan sengketa hukum diluar pengadilan demi keuntungan para pihak, mengurangi biaya litigasi konvensional dan pengunduran waktu yang

3 J Folberg and A Taylor, 1984, Mediation : A Comprehensive Guide to Resolving Conflict Without Litigation, Australia: Butterwortis, hlm. 4

4 Priyatna Abdurrasyid, Arbitrase dan Alternatif..... Op.,Cit., hlm. 17

5 Ibid. 
biasa terjadi dan mencegah terjadinya sengketa hukum yang biasanya diajukan ke pengadilan.

Alternatif penyelesaian sengketa termasuk arbitrase dapat diberi batasan sebagai sekumpulan prosedur atau mekanisme yang berfungsi memberi alternatif atau pilihan atau suatu tatacara penyelesaian sengketa melalui bentuk negosiasi, mediasi, konsiliasi dan arbitrase. Semua tata cara penyelesaian sengketa berdasarkan itikad baik dimana para pihak yang bersengketa menyampaikan pokok persoalannya melalui jalurnya sendiri dengan cara bagaimana sengketa akan diselesaikan melalui jalur mediasi atau jalur yang lain.

Apabila jalur mediasi yang dipilih oleh para pihak maka ada beberapa unsur dalam mediasi yaitu adanya sengketa antara dua pihak atau lebih, adanya kemauan menyelesaiakn sengketa melalui mediasi, adanya mediator. Akan tetapi dalam hal ini tugas mediator hanya memberikan saran-saran atau tidak sebagaimana halnya seorang hakim atau arbiter, seorang mediator tidak dalam posisi (tidak mempunyai kewenangan) untuk memutus sengketa para pihak. Tugas dan kewenangan mediator hanya membantu dan memfasilitasi pihak-pihak yang bersengketa dapat mencapai suatu keadaan untuk dapat mengadakan kesepakatan tentang hal-hal yang disengketakan.

Salah satu jiwa hukum adalah keadilan. Tidak kelebihan jika dibilang produk hukum adalah salah satu sarana untuk menciptakan dan mendapatkan rasa keadilan bagi masyarakat. Oleh karena itu hukum yang baik harus mempunyai nilai-nilai keadilan dan kemanfaatan. Sehingga peraturan mediasi perbankan dibuat dalam rangka menciptakan rasa keadilan bagi masyarakat terutama adalah nasabah. ${ }^{6}$

Ruang lingkup Mediasi hanya dapat dilaksanakan dan dipergunakan sebagai cara penyelesaian sengketa diluar jalur pengadilan (Out-of court Settlement) untuk sengketa perdata yang timbul diantara para pihak, dan bukan perkara pidana maupun Tata Usaha Negara. Sehingga, setiap sengketa perdata dibidang perbankan (termasuk yang diatur dalam PBI No.8/5/PBI/2006) dapat diajukan dan untuk diselesaikan melalui Lembaga Medasi Perbankan. Akan tetapi untuk perkara pidana dan mungkin juga sengketa Tata Usaha Negara seringkali dalam praktek dipergunakan dengan jalan musyawarah mufakat (melelui mediasi), akan dituangkan dalam suatu perjanjian perdamaian, dan dipahami juga bahwa walau para pihak tidak dapat dibenarkan membuat perjanjian perdamaian bagi perkara pidana mereka dapat menggunakan perjanjian perdamaian atas sengketa perdata mereka sebagai dasar untuk dengan itikad baik sepakat tidak melanjutkan perkara pidana yang timbul diantara mereka dan/atau mencabut laporan perkara pidana tertentu, sebagaimana dimungkinkan. ${ }^{7}$

6 Susanti Adi Nugroho, 2009, Mediasi Sebagai Alternatif Penyelesaian Sengketa, Jakarta: PT. Telaga Ilmu Indonesia, hlm. 212

7 Felix Oentoeng Soebagjo, "Mediasi sebagai alternatif Penyelesaian Sengketa di Bidang Perbankan", http://www.bakti-arb.org/pdf/PelaksanaanMediasi_FelixSoebagjo.pdf, diakses tanggal 1 November 2016 
Berdasarkan Peraturan Bank Indonesia Nomor 10/1/PBI/2008 tentang Mediasi Perbankan perubahan atas Peraturan Bank Indonesia Nomor 8/5/PBI/2006 tersebut penyelesaian sengketa dapat dilaksanakan oleh Mediasi Perbankan yang sedianya akan dilaksanakan oleh Lembaga Mediasi Independen. Namun mengingat Lembaga Mediasi Independen belum dapat dibentuk oleh Asosiasi Perbankan, maka fungsi Mediasi Perbankan untuk sementara dilaksanakan oleh Bank Indonesia. Proses mediasi perbankan merupakan kelanjutan dari pengaduan nasabah apabila nasabah merasa tidak puas atas penanganan dan penyelesaian yang diberikan bank. Fungsi mediasi yang dilaksanakan oleh Bank Indonesia terbatas pada upaya membantu nasabah dan bank untuk mengkaji ulang permasalahan atau sengketa yang timbul di antara mereka untuk memperoleh kesepakatan.

Peraturan Bank Indonesia (PBI) tentang Mediasi Perbankan mengatur bahwa sebelum dibawa ke lembaga mediasi perbankan, setiap sengketa antara nasabah dengan bank harus diselesaikan lebih dulu secara internal oleh bank yang bersangkutan. Jika penyelesaian tersebut tidak memperoleh kata sepakat, nasabah dapat membawa masalah tersebut ke lembaga mediasi perbankan Bank Indonesia.

Beberapa langkah bagi pihak nasabah dan bank untuk melakukan mediasi perbankan yaitu sebagai berikut: ${ }^{8}$

a. Langkah pertama :

1) Minta penjelesan kepada bank mengenai penyelesaian sengketa melalui mediasi perbankan;

2) Pahami surat hasil penyelesaian pengaduan dari bank sebagai tanggapan terhadap permasalahan yang nasabah adukan;

3) Terhadap surat bank tersebut, nasabah dapat menerima atau menolak keputusan yang diberikan bank;

4) Apabila nasabah tidak sepakat dengan bank, maka nasabah mempunyai beberapa pilihan untuk menyelesaikan sengketa dengan bank, yaitu dengan mediasi perbankan, arbitrase, alternative penyelesaian sengketa lainnya atau jalur pengadilan;

5) Apabila nasabah memilih menggunakan mediasi perbankan sebagai alternatif penyelesaian sengketa dapatkan informasi mengenai prosedur dan tatacara penyelesaian sengketa melalui mediasi perbankan tersebut dari bank; dan

6) Pengajuan penyelesaian sengketa melalui Mediasi Perbankan dapat dilakukan oleh nasabah atau perwakilan nasabah.

7) Pastikan sengketanya dapat di mediasi sesuai ketentuan Bank Indonesia, sengketa dapat diselesaikan melalui mediasi perbankan apabila :

a) Diajukan secara tertulis disertai dokumen pendukung yang memadai;

8 Peraturan Bank Indonesia Nomor 8/5/PBI/2006 tentang Mediasi Perbankan yang kemudian dirubah dengan PBI No.10/1/PBI/2008 tentang Mediasi Perbankan 
b) Pernah diupayakan penyelesaian oleh bank;

c) Sengketa yang diajukan tidak sedang dalam proses atau belum pernah diputus oleh lembaga arbitrase atau peradilan atau belum terdapat kesepakatan;

d) Sengketa yang diajukan merupakan sengketa keperdataan;

e) Sengketa yang diajukan belum pernah di proses dalam mediasi perbankan yang difasilitasi oleh Bank Indonesia;

f) Pengajuan penyelesaian sengketa tidak melebihi 60 hari kerja sejak tanggal surat hasil penyelesaian pengaduan yang disampaikan bank pada nasabah;

g) Nilai tuntutan financial yang diajukan paling banyak sebesar Rp. 500.000.000 setiap kasus sengketa; dan

h) Nasabah tidak mengajukan tuntutan financial yang diakibatkan oleh kerugian immateril.

b. Langkah Kedua :

Ajukan permohonan penyelesaian sengketa kepada pelaksana fungsi mediasi perbankan.

1) Sampaikan permohonan penyelesaian sengketa kepada pelaksana fungsi mediasi perbankan secara tertulis sesuai dengan format yang telah ditetapkan dan sertakan dokumen pendukung;

2) Sesuai ketentuan Bank Indonesia, dukumen pendukung yang harus dilampirkan adalah :

1). Salinan surat hasil penyelesaian pengaduan yang diberikan bank pada nasabah; dan

2). Salinan Identitas Diri yg masih berlaku;

3) Surat pernyataan yang ditandatangani diatas matarei yang cukup bahwa sengketa yg diajukan tidak sedang diproses atau telah mendapatkan keputusan dari lembaga arbitrase, peradilan, atau lambaga mediasi lainnya dan belum pernah diproses melalui mediasi perbankan yang difasilitasi oleh Bank Indonesia;

4) Salinan dokumen pendukung yang terkait dengan sengketa yang diajukan;

5) Salinan surat kuasa khusus tanpa hak substitusi dalam hal pengajuan penyelesaian sengketa diwakilkan/ dikuasakan; dan

6) Berikan penjelasan yang selengkap-lengkapnya kepada pelaksana fungsi mediasi perbankan mengenai permasalahan yang diajukan dan upaya-upaya penyelesaian yang telah dilakukan oleh Bank.

c. Langkah ketiga :

Ikuti proses Mediasi. Dalam membantu penyelesaian sengketa, pelaksana fungsi mediasi perbankan akan melakukan beberapa kegiatan yang memerlukan partisipasi bank dan nasabah :

1) Penandatanganan perjanjian mediasi. 
Penuhi panggilan pelaksana fungsi mediasi perbankan untuk mendapatkan penjelasan tentang tata cara proses mediasi dan perjanjian mediasi yang memuat :

a) Kesepakatan untuk memilih mediasi sebagai alternativ penyelesaian sengketa; dan

b) Persetujuan untuk patuh dan tunduk pada peraturan mediasi yang ditetapkan oleh pelaksana fungsi mediasi perbankan.

Apabila nasabah dan bank telah memahami proses mediasi dan sepakat terhadap isi perjanjian mediasi maka nasabah dan bank melakukan penandatanganan perjanjian mediasi. Jadi Proses Mediasi Perbankan dilaksanakan setelah nasabah atau perwakilan nasabah dan Bank menandatangani perjanjian Mediasi (agreement to mediate) atau perjanjian.

2) Pertemuan dalam rangka pelaksanaan proses mediasi.

Ikuti pertemuan dengan bank yang difasilitasi oleh mediator dalam rangka mencapai penyelesaian terhadap masalah yang disengketakan. Dalam rangka pelaksanaan proses mediasi tersebut. Mediator bersifat netral dan tidak memberikan rekomendasi dan keputusan.

3) Penandatangan Akte Kesepakatan

Anda harus menandatangani akta kesepakatan dengan bank yang dihasilkan dari proses mediasi. Akta kesepakatan dapat memuat kesepakatan penuh atau kesepakatan sebagian atas hal yang dipersengketakan, atau pernyataan tidak dicapainya kesepakatan dalam proses mediasi.

d. Langkah keempat : Laksanakan akta kesepakatan

1) Lakukan seluruh hal-hal yang disepakati dalam akta kesepakatan;

2) Laporkan kepada pelaksana fungsi mediasi realisasi akta kesepakatan; dan

3) Apabila nasabah dan bank tidak mencapai kesepakatan dalam proses mediasi perbankan, anda dapat melanjutkan upaya penyelesaian sengketa melalui arbitrase atau jalur peradilan.

Berdasarkan tersebut diatas, maka analisa penulis adalah seharusnya nilai tuntutan financial atau nilai sengketa tidak dibatasi hanya sebatas maximal sebesar Rp. 500,000,000,- . Akan tetapi seharusnya nilai sengketa yang lebih dari Rp 500.000.000 juga dapat diselesaikan melalui mediasi perbankan. Karena tujuan utama mediasi adalah membantu mencarikan jalan keluar/alternative penyelesaian atas sengketa yang timbul diantara para pihak yang disepakati dan dapat diterima oleh para pihak yang bersengketa dan dengan demikian proses negosiasi adalah proses yang forward looking dan bukan backward looking. Yang hendak dicapai bukanlah mencari kebenaran 
dan/atau dasar hukum yang diterapkan namun lebih kepada penyelesaian masalah ("The goal is not truth finding or law imposing, but problem solving”). ' Jadi nilai sengketa diatas Rp. 500.000.000,seharusnya juga dapat diselesaikan melalui mediasi perbankan tersebut.

Terhadap mediasi perbankan ini juga seharusnya tuntutan financial karena adanya kerugian immateril oleh nasanah bisa dilakukan oleh nasabah. Karena dalam mediasi ini ruang lingkupnya hanya untuk sengketa-sengketa yang berkaitan dengan sengketa perdata sehingga ruang lingkupnya seharusnya tidak dibatasi, akan tetapi tergantung dari para pihak.

Apabila nasabah akan diwakilkan oleh wakilnya untuk melakukan mediasi perbankan melalui surat kuasa khusus. Akan tetapi, surat kuasa khusus tersebut tanpa hak substitusi. Maka hal ini akan membatasi wakilnya atau kuasa hukumnya dalam melakukan tugasnya dalam arti bahwa wakilnya harus siap setiap saat dengan jadwal mediasi yang telah ditentukan. Sehingga jalan keluarnya adalah wakil atau kuasa hukumnya harus memasukkan nama-nama dari kuasa hukumnya tidak hanya satu saja, akan tetapi sebaiknya lebih dari satu atau lebih banyak lebih baik. Karena apabila salah satu tidak bisa hadir maka masih ada yang lainnya.

Perumusan sengketa didalam Pasal 1 angka 4 memberikan devinisi tentang sengketa adalah permasalahan yang diajukan oleh Nasabah atau Perwakilan Nasabah kepada penyelenggara mediasi perbankan, setelah melalui proses penyelesaian pengaduan oleh Bank sebagaimana diatur dalam Peraturan Bank Indonesia tentang Penyelesaian Pengaduan Nasabah. Berdasarkan devinisi tersebut mengapa hanya Nasabah yang didefinisikan sebagai pihak dalam Sengketa dan apakah bank merasa tidak perlu untuk ikut serta sebagai pihak dalam suatu sengketa serta sebagai pihak yang mengajukan klaim. Hal ini menimbulkan mengkhawatirkan, jika pihak yang mengajukan permasalahan hanyalah nasabah, dan pihak bank merasa tidak mempunyai sengketa, tidak bersedia menandatangani Agreement to Mediate, maka tujuan pembentukan lembaga mediasi perbankan akan sangat sulit dicapai.

9 Peter Lovenheim, How to Mediate Your Dispute, Nolo-Press: Berkeley, 1996 
GAMBAR 1

4 (empat) Langkah Mediasi Perbankan

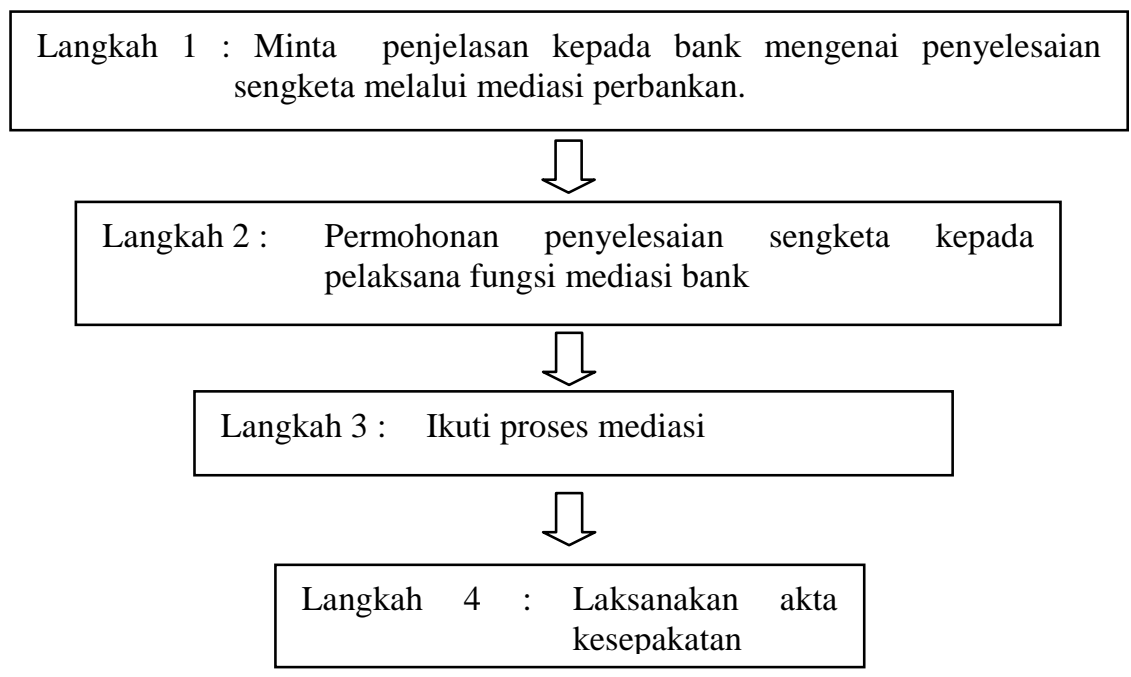

\section{Keuntungan dan Kelemahan dari Mediasi Perbankan}

a. Keuntungan dari mediasi perbankan.

Pada umumnya sengketa perbankan diselesaikan melalui proses pengadilan. Dalam kondisi ini nasabah biasanya akan dihadapi oleh beberapa hal yaitu : ${ }^{10}$

1) Biaya yang diperlukan terkadang cukup besar, sedangkan tidak jarang nilai sengketa tidak terlalu besar;

2) Waktu yang diperlukan relatif lebih lama dan proses yang panjang, apabila jika pihak lawan tidak memenuhi jadwal sidang yang telah ditentukan sehingga sidang harus ditunda untuk waktu yang lama seperti seminggu atau dua minggu untuk penundaan sidang;

3) Proses pemeriksaan yang terbuka untuk umum, mempengaruhi kredibilitas nasabah dan bank;

4) Sengketa antara nasabah dengan bank biasanya menempatkan posisi nasabah pada posisi dibawah bank. Apalagi kurang baiknya citra peradilan ditengah masyarakat;

5) Hakim akan memutus ada yang kalah dan yang menang sehingga kurang kondusif bagi kelanjutan hubungan para pihak yang bersengketa; dan

6) Rasa keadilan dan kepastian terhadap putusan hakim.

Sedangkan bagi pihak bank sendiri proses pengadilan ini juga bisa menimbulkan hal-hal yang kurang menguntungkan antara lain: ${ }^{11}$

1) Waktu dan proses yang relatif lama dapat menganggu operasional lain dari bank;

2) Sidang yang terbuka untuk umum, dapat menimbulkan citra yang kurang baik terhadap bank; dan

\footnotetext{
10 Susanti Adi Nugroho, Mediasi Sebagai........ Op., Cit., hlm. 212-213

11 Ibid.
} 
3) Banyaknya kasus yang belum terselesaikan, akibat waktu yang panjang, dapat menimbulkan rasa ketidak kepercayaan terhadap bank.

Melalui proses mediasi diharapkan dapat dicapai terjalinnya komunikasi yang lebih baik diantara para pihak yang bersengketa. Menjadikan para pihak yang bersengketa dapat mendengar, memahami alasan/ penjelasan/ aurgumentasi yang menjadi dasar/pertimbangan pihak yang lain. Dengan adanya pertemuan tatap muka, diharapkan dapat mengurangi rasa marah/bermusuhan antara pihak yang satu dengan yang lain. Memahami kekurangan / kelebihan / kekuatan masing-masing, dan ha ini diharapkan dapat mendekatkan cara pandangdari pihak-pihak yang bersengketa, menuju suatu kompromi yang dapat diterima para pihak.

Mediasi perbankan berusaha untuk memecahkan kelemahan dari proses pengadilan tersebut dan berupaya memberikan keadilan terhadap pihak-pihak yang bersengketa. Upaya penyelesaian sengketa antara nasabah dan bank memang dapat dilakukan melalui negosiasi, konsiliasi, mediasi, arbitrase, atau lewat jalur peradilan. Namun demikian, upaya penyelesaian sengketa melalui arbitrase atau jalur peradilan tidak mudah dilakukan bagi nasabah kecil dan usaha mikro dan kecil mengingat hal tersebut memerlukan waktu dan biaya yang tidak sedikit. Sengketa antara nasabah kecil dan usha mikro dengan bank akan realtif lebih mudah diselesaikan melalui cara mediasi Sehingga mediasi mempunyai keunggulan dalam proses mediasi perbankan yaitu sebagai berikut: ${ }^{12}$

1) Proses mediasi didasarkan pada prinsip acara yang sederhana sehingga waktu yang diperlukan relatif lebih cepat;

2) Dalam proses mediasi para pihak ditempatkan pada posisi yang setara dan memiliki kesempatan yang sama untuk berpartisipasi secara langsung;

3) Mediator yang menegahi sengketa para pihak ditunjuk sendiri berdasarkan kesepakatan para pihak;

4) Mediator yang ditunjuk adalah orang yang memiliki pengetahuan dan keahlian dalam bidangnya;

5) Penyelesaian atas sengketa diputuskan sendiri oleh para pihak yang bersengketa.

6) Pelaksanaan hasil kesepakatan mediasi oleh para pihak dilakukan secara sukarela tanpa ada paksaan salah satu pihak;

7) Tidak dipungut biaya;

8) Jangka waktu proses mediasi paling lambat 60 (enam puluh) hari; dan

9) Proses mediasi dilakukan secara informal/fleksibel

12 Ibid., hlm. 213 
Bank akan dikenakan sanksi administrative sesuai Pasal 52 UU No.7 tahun 1992 yang diubah dengan UU No.10 tahun 1998, berupa teguran tertulis dan dapat diperhitungkan dalam komponen penilaian tingkat kesehatan bank, apabila:

1) Bank tidak memenuhi panggilan BI dalam hal nasabah/perwakilan nasabah mengajukan penyelesaian sengketa kepada Bank Indonesia;

2) Bank tidak mengikuti dan mentaati perjanjian mediasi yang telah ditandatangani oleh nasabah/perwakilan nasabah dan bank;

3) Bank tidak melaksanakan hasil penyelesaian sengketa perbankan antara nasabah dengan bank yang telah disepakati dan dituangkan dalam akta kesepakatan; dan

Bank tidak mempublikasikan kepada nasabah adanya sarana alternative penyelesaian sengketa di bidang perbankan dengan cara mediasi.

b. Kelemahan dari mediasi perbankan

Kelemahan Regulasi Mediasi Perbankan adalah PBI No.8/5/PBI/2006 yang kemudian dirubah dengan PBI No.10/1/PBI/2008 tentang Mediasi Perbankan dalam prakteknya ternyata memiliki beberapa kelemahan yakni:

1) Pembentukan Lembaga Mediasi Perbankan yang diserahkan oleh asosiasi perbankan, pada prakteknya ternyata waktu yang ditenggatkan oleh PBI No.8/5/PBI/2006 yakni tanggal 31 Desember 2007 tidak juga terbentuk hingga sekarang, sehingga melalui PBI No.10/1/PBI/2008 tenggat waktu tersebut dihilangkan. Hal ini disebabkan; pertama, tidak terpenuhinya target pemenuhan modal minimum bank umum pada tahun 2007. Karena pembentukan LMP mensyaratkan bank untuk menyalurkan dananya di LMP. Kedua, masalah teknis pelaksanaan, mulai masalah badan hokum, mediator hingga teknis di lapangan. Ketiga, tidak tercapainya kesepakatan mengenai biaya yang dikeluarkan untuk operasional LMP.

2) Terlaksananya Mediasi Perbankan tergantung pada bank, karena yang mengajukan permohonan ke mediasi perbankan adalah nasabah atau perwakilan nasabah, namun sebenarnya dapat tidaknya penyelesaian sengketa perbankan melalui mediasi perbankan sangat bergantuang pada iktikad baik bank. Banklah yang menentukan apakah sutau sengketa dapat diselesaikan melalui mediasi perbankan ataukah dengan cara lain.

3) Efektifitas Akta kesepakatan Mediasi, yang bergantung pada iktikad baik bank untuk mentaati hasil kesepakatan tersebut, karena memang tidak ada satu klausula pun yang mengikat tentang pelaksanaan akta kesepakatan mediasi. Inilah yang kemudian tidak memiliki konsekuensi hokum apabila salah satu 
pihak melakukan wan prestasi atas akta kesepakatan mediasi. Di sini juga regulasi yang ada tidak mengatur tentang bagaimana mekanisme apabila salah satu pihak tidak memenuhi prestasinya, apakah bisa dilanjutkan ke jalur arbitrase atau peradilan.

4) Penyelenggaraan lembaga mediasi perbankan diatur oleh Peraturan Bank Indonesia (PBI) No. 8/5/PBI/2006 yang kemudian dirubah dengan PBI No.10/1/PBI/2008 tentang Mediasi Perbankan. Banyak kalangan yang meragukan keabsahan PBI sebagai dasar pengaturan mediasi perbankan, mengingat baik dalam UU Perbankan maupun UU Bank Indonesia tidak ditemukan adanya perintah langsung yang secara tegas dan jelas memerintahkan pengaturan lebih lanjut mediasi perbankan, melalui peraturan Bank Indonesia.

Ada beberapa masalah hukum yang terkait dengan pembentukan lembaga mediasi perbankan sebagai berikut $:^{13}$

1) Menyangkut formalitas pembentukan.

Karena belum ada landasan hukum positif di Indonesia yang dapat dijadikan landasan yuridis formal dan yuridis material sebagai landasan pembentukan lembaga mediasi perbankan ini. $^{14}$

Masalah lain adalah siapa yang akan membentuk lembaga tersebut apakah Bank Indonesia, asosiasi usaha perbankan, atau yang lainnya. Oleh karenanya perlu diperhatikan landasan yuridis formalnya.

2) Menyangkut substansi peraturan.

Segi substansi dari produk hukum yang menjadi dasar pembentukan lembaga mediasi perbankan independen pada pokoknya meliputi permasalahan terkait dengan pelaksanaan mediasi perbankan, seperti lingkup sengketa yang bisa dimediasikan, batasan sengketa, dan teknik prosedural acara mediasi yang akan dijalankan oleh lembaga yang bersangkutan.

Ada pendapat dari Bismar Nasution ${ }^{15}$ yang menyatakan bahwa

Peraturan Bank Indonesia (PBI) memiliki dasar yang kuat dalam pengaturan mediasi perbankan. Walaupun didalam Undang-Undang tidak ada perintah langsung untuk menerbitkan PBI tentang mediasi perbankan. Akan tetapi apabila dilihat dari Pasal 8 dan pasal 24 UU No. 23 Tahun 1999 tentang Bank Indonesia yang menyatakan, "Untuk mencapai tujuan sebagaimana dimaksud dalam Pasal 7, Bank Indonesia mempunyai tugas sebagai berikut :

1) menetapkan dan melaksanakan kebijakan moneter;

3 Ibid., hlm. 217 hlm. 218

Zulkarnaian Sitompul, Problematika Perbankan, Bandung: Book Terrace \& Library, 2005,

15 Susanti Adi Nugroho, Loc., Cit. 
2) mengatur dan menjaga kelancaran sistem pembayaran;

3) mengatur dan mengawasi Bank". ${ }^{16}$

Pasal 24 berbunyi, "Dalam rangka melaksanakan tugas sebagaimana dimaksud dalam Pasal 8 huruf c, Bank Indonesia menetapkan peraturan, memberikan dan mencabut izin atas kelembagaan dan kegiatan usaha tertentu dari Bank, melaksanakan pengawasan Bank, dan mengenakan sanksi terhadap Bank sesuai dengan ketentuan perundang-undangan". ${ }^{17}$

Berdasarkan pasal diatas menugaskan kepada BI untuk mengatur dan mengawasi Bank, Hal ini merupakan dasar yang kuat bagi BI untuk menerbitkan aturan tersebut. BI juga dapat mengeluarkan peraturan tentang mediasi sebagai bagian tugas mengatur yang diberikan oleh Undang-undang kepadanya.

\section{SIMPULAN}

Mediasi perbankan berusaha untuk memecahkan kelemahan dari proses pengadilan dan berupaya memberikan keadilan terhadap pihak-pihak yang bersengketa karena dengan mediasi perbankan para pihak akan lebih banyak mendapat keuntungan dari pada melalui proses pengadilan. Ada empat langkah dalam mediasi perbankan yaitu minta kejelasan kepada bank mengenai penyelesaian sengketa melalui mediasi perbankan, permohonan penyelesaian sengketa kepada pelaksana fungsi mediasi bank, ikut proses mediasi dan laksanakan akta kesepakatan. Akan tetapi, ada hal yang harus diperhatikan yaitu nilai tuntutan financial atau nilai sengketa tidak dibatasi hanya sebatas maximal sebesar Rp. 500,000,000,- .Akan tetapi seharusnya nilai sengketa yang lebih dari Rp 500.000.000 juga dapat diselesaikan melalui mediasi perbankan, nasabah akan diwakilkan oleh wakilnya untuk melakukan mediasi perbankan melalui surat kuasa khusus. Akan tetapi, surat kuasa khusus tersebut tanpa hak substitusi. Maka hal ini akan membatasi wakilnya atau kuasa hukumnya dalam melakukan tugasnya dalam arti bahwa wakilnya harus siap setiap saat dengan jadwal mediasi yang telah ditentukan dan menimbulkan anggapan dari devinisi sengketa dalam Pasal 1 angka 4 PBI bahwa jika pihak yang mengajukan permasalahan hanyalah nasabah, dan pihak bank merasa tidak mempunyai sengketa, tidak bersedia menandatangani Agreement to Mediate, maka tujuan pembentukan lembaga mediasi perbankan akan sangat sulit dicapai.

Ada beberapa masalah hukum yang terkait dengan pembentukan lembaga mediasi perbankan yaitu Karena belum ada landasan hukum positif di Indonesia yang dapat dijadikan landasan yuridis formal dan yuridis material sebagai landasan pembentukan lembaga mediasi perbankan ini dan Segi substansi dari produk hukum yang menjadi dasar pembentukan lembaga mediasi perbankan independen pada pokoknya meliputi permasalahan terkait dengan pelaksanaan mediasi perbankan, seperti lingkup sengketa yang bisa dimediasikan, batasan

16 Undang-Undang No. 23 Tahun 1999 tentang Bank Indonesia

17 Ibid. 
sengketa, dan teknik prosedural acara mediasi yang akan dijalankan oleh lembaga yang bersangkutan.

\section{DAFTAR PUSTAKA}

Buku :

Abdurrasyid, Priyatna. 2011. Arbitrase dan Alternatif Penyelesaian Sengketa, Jakarta: PT. Fikahati Aneska

Adi Nugroho, Susanti. 2009. Mediasi Sebagai Alternatif Penyelesaian Sengketa Jakarta: PT. Telaga Ilmu Indonesia

Folberg, Jay, dan Allison Taylor. 1984. Mediation : A Comprehensive Guide to Resolving Conflict Without Litigation, Australia: Butterwortis

Fuady, Munir. 1999. Hukum Perbankan Modern, Bandung: Citra Aditya Bhakti

Lovenheim, Peter. 1996. How to Mediate Your Dispute, Berkeley: Nolo-Press

Sitompul, Zulkarnaian. 2005. Problematika Perbankan, Bandung: Book Terrace \& Library

\section{Internet :}

Felix Oentoeng Soebagjo, "Mediasi sebagai alternatif Penyelesaian Sengketa di Bidang Perbankan”,http://www.bakti-arb.org/pdf/PelaksanaanMediasiFelixSoebagjo.Pd f, di akses tanggal 1 November 2016

\section{Peraturan Undang-undangan :}

Undang-Undang No. 23 Tahun 1999 tentang Bank Indonesia

Peraturan Bank Indonesia Nomor 8/5/PBI/2006 tentang Mediasi Perbankan yang kemudian dirubah dengan PBI No.10/1/PBI/2008 tentang Mediasi Perbankan. 